\title{
New Drug Combination Strategies in Melanoma: Current Status and Future Directions
}

\author{
AHMAD NAJEM $^{1 *}$, MOHAMMAD KRAYEM $^{1 *}$, ANNE PERDRIX $^{1,2}$, JOSEPH KERGER $^{3}$, \\ AHMAD AWADA $^{3}$, FABRICE JOURNE ${ }^{1,4}$ and GHANEM GHANEM ${ }^{1}$ \\ ${ }^{1}$ Laboratory of Oncology and Experimental Surgery and ${ }^{3}$ Department of Medical Oncology, \\ Institute Jules Bordet, Université Libre de Bruxelles, Brussels, Belgium; \\ ${ }^{2}$ Department of Biopathology and INSERM U1245, Centre Henri Becquerel, Rouen, France; \\ ${ }^{4}$ Department of human anatomy and experimental oncology, University de Mons, Mons, Belgium
}

\begin{abstract}
Melanoma is the deadliest form of skin cancer and one of the most difficult cancers to treat. Overall, melanomas have more mutations than any other cancer type. Oncogenic mutations in c-KIT, NRAS and BRAF components of the MAPK pathway have been identified in nearly $90 \%$ of cutaneous melanoma and this information has been used to develop small molecules that inhibit their activity. Highly selective BRAF and MEK inhibitors have demonstrated impressive clinical results. However, the short duration of response, the acquired resistance in most cases and the toxicity issues support the rationale for drug combination approaches to improve the outcome of MAPK inhibitors, increase their efficacy, prevent and/or overcome resistance. This review discusses several promising rational combinatorial strategies investigated or could be investigated in clinical studies.
\end{abstract}

Incidence and mortality rates for melanomas, the most common form of cancer in people aged from 25 to 29 , continue to rise faster than any other cancer type. Although melanoma accounts for only a small percentage of skin cancers, it is responsible for the majority of deaths of all skin cancers $(1,2)$. Increased understanding of the molecular

This article is freely accessible online.

*These Authors contributed equally to this study.

Correspondence to: Prof. G. Ghanem, Laboratory of Oncology and Experimental Surgery, Institute Jules Bordet, 1 rue Héger-Bordet, 1000 Brussels, Belgium. Tel: +32 0254132.97, e-mail: gghanem@ulb.ac.be

Key Words: MAPK, drug resistance, targeted therapies, immunotherapy, radiotherapy, $\mathrm{p} 53$, review. events involved in melanoma development has led to the identification of novel targets and to the development of new targeted agents. Gene alterations identified in melanoma pointed to distinct molecular subsets of tumors with direct implications in therapeutic strategies. Among these, activating BRAF mutations occur in 50-60\% of melanomas (V600E substitution represents about $90 \%$ of BRAF mutations), NRAS mutations in $20-30 \%$ of melanomas (mutually exclusive with BRAF mutation), KIT mutations and/or amplification in 39\% of mucosal and $36 \%$ of acral melanomas $(3,4)$. These mutations opened new therapeutic perspectives targeting the MAPK pathway (hyperactivated in $90 \%$ of melanomas) with ${ }^{2600 E}$ BRAF, MEK or RTK inhibitors (5-7).

Vemurafenib and dabrafenib, specific inhibitors of the mutant BRAF (V600E), have been approved by the Food and Drug Administration (FDA) in 2011 and 2013 respectively, for the treatment of patients with unresectable or metastatic melanoma carrying the V600E mutation in BRAF. Furthermore, trametinib a selective inhibitor of MEK1/2 was approved for the same indication in 2013. The approval of these inhibitors was based on improved rates of overall and progression-free survival compared to chemotherapy in phase III clinical trials $(6,8,9)$. Moreover, among new MEK inhibitors in clinical development, pimasertib and binimetinib (MEK 162) have been recently reported to be particularly promising in the case of patients with mutant NRAS melanoma (10-12). Finally, the results of clinical trials evaluating RTK inhibitors sunitinib and imatinib in patients presenting mutated $c$-KIT have been published and showed an average response rate of $20 \%(7,13)$.

Targeting MAPK pathway in melanoma with MAPK inhibitors has shown clinical benefit. However, the short duration of response and progression-free survival in patients due to resistance or to general toxicity indicate that 
combination therapeutic strategies are needed to enhance the effect of MAPK inhibitors. Therefore, efforts are ongoing to further understand resistance mechanisms and also to improve the outcome of MAPK inhibitors by rational use of combination therapy.

\section{Current Combinations of Targeted Therapies and Perspectives}

Cotargeting MAPK pathway at multiple levels. Regardless of the encouraging results obtained with the BRAF inhibitors dabrafenib or vemurafenib, the majority of patients develop resistance to BRAF inhibitors and relapse (14). In most cases, resistance is associated with reactivation of the MAPK pathway $(15,16)$. In addition, BRAF inhibitor-induced paradoxical activation of the MAPK pathway in RAS mutant cells and in wild-type BRAF cells, can result in secondary cancers, including cutaneous squamous-cell carcinoma (17-19). In this context, we reported the prominent role of cyclic AMP signaling pathway in the sensitivity of ${ }^{\mathrm{WT}} \mathrm{BRAF} /{ }^{\mathrm{WT}} \mathrm{NRAS}$ melanoma cells to vemurafenib (20). We found that cells with low phospho-CRAF and high cAMP levels are sensitive to vemurafenib while in the resistant ones phospho-CRAF expression was high; and CRAF inhibition through cAMP stimulation overcame the resistance to the drug.

The MEK inhibitor trametinib, also improves the overall survival of patients with the BRAF V600E mutation compared with chemotherapy, and is not associated with paradoxical activation of the MAPK pathway (6). Further, the idea of combining a BRAF inhibitor with a MEK inhibitor has been tested for the treatment of BRAF mutated melanomas. Interestingly, this regimen blocks the MAPK pathway at two signaling points and can reduce the cutaneous toxicity related to the paradoxical reactivation of the MAPK pathway (21-23). Most importantly, phase III trials have shown that combined BRAF and MEK inhibition, compared with BRAF inhibition alone, delays the emergence of resistance and reduces toxic effects (24) (Table I). For instance, it was shown in two independent phase III trials, that the combination of dabrafenib and trametinib, compared with dabrafenib alone or the combination of vemurafenib plus cobimetinib, compared with vemurafenib alone significantly improved the progression-free survival, the overall survival and the objective response rate (complete plus partial) (24-26).

The rate of cutaneous squamous cell carcinoma highly decreased with the combination compared to the BRAF inhibitors alone (24-26). The combination of these inhibitors have been approved by the FDA in 2014 (dabrafenib and trametinib) and 2015 (vemurafenib and cobimetinib) for patients with unresectable or metastatic melanoma with a BRAF V600E or V600K mutation. The combination of BRAF and MEK inhibition also showed a synergistic effect on the growth inhibition of NRAS mutant melanoma cells when there is a higher activity of the MAPK pathway and dependence of proliferation and survival on this pathway (27). Inhibition of ERK $1 / 2$ is also a promising strategy in melanoma. SCH772984 is a new selective inhibitor of ERK1/2 that has demonstrated antitumor activity in preclinical studies, against BRAF mutant, NRAS mutant and wild-type melanoma (28). Other selective ERK1/2 inhibitors as GDC-0994 are currently ongoing clinical trials as single agent (NCT01875705) or in combination with MEK inhibitors (NCT02457793) (Table I). Consequently, these findings provide a rationale for cotargeting MAPK pathway at multiple nodes (Figure 1) and suggest that this therapeutic strategy is a more effective one.

Co-targeting of MAPK and PI3K/AKT signaling pathways. $\mathrm{PI} 3 \mathrm{~K} / \mathrm{AKT}$ pathway is frequently activated in melanoma. Activating mutation of c-KIT and NRAS can lead to constitutive activation of PI3K-AKT pathways $(29,30)$. In BRAF mutant melanoma, we showed that PI3K/AKT activation is associated with intrinsic and acquired resistance to BRAF inhibition (31).

Constitutive activation of PI3K/AKT pathway is due to multiple mechanisms $(15,32-34)$ including the loss of the tumor suppressor PTEN (20-30\% of melanomas) that confers resistance to MAPK inhibition in melanoma (35-37). Therefore, acquired and innate oncogenic alteration in the PI3K/AKT signaling can explain the inefficiency of single pathway inhibition and the rationale for the concurrent targeting of both MAPK and PI3K/AKT pathways (Figure 1) to counteract resistance and obtain beneficial long-term clinical effects. Several studies have demonstrated antitumor activity and pointed out synergistic effect of cotargeting MAPK and PI3K/AKT pathways in BRAF and NRAS mutant melanomas $(22,24,31,38-40)$.

Otherwise, clinical studies have investigated the combination of MAPK and PI3K/AKT inhibitors in melanoma and other solid tumors (Table I). For instance, phase $1 \mathrm{~b}$ combination trial of a MEK inhibitor, pimasertib (MSC1936369B), and a PI3K/mTOR inhibitor, SAR245409, was investigated in patients with locally advanced or metastatic solid tumors (NCT01390818). The combination of BYL719 (PI3K inhibitor) and binimetinib (MEK inhibitor) was studied in patients with advanced solid tumors (NCT01449058). Also, a phase I trial of BKM120 (PI3K inhibitor) combined with vemurafenib was also evaluated in V600E/K $\mathrm{BRAF}$ mutant advanced melanoma. Preliminary data show that these combinations are tolerated and active. However, data presented to date have only shown modest clinical activity of the combination. The efficiency of dual targeting could be increased by optimal dosing/timing schedules, or enriching the patients with predictive factors. Co-targeting of MAPK and p53 pathways. As a guardian of 
Table I. Selected clinical trials of combined strategies in melanoma.

\begin{tabular}{|c|c|c|c|c|}
\hline Agents & Phase & Sponsor & Patients & NCT \\
\hline $\begin{array}{l}\text { Dabrafenib (BRAF inhibitor) + } \\
\text { Trametinib (MEK inhibitor) }\end{array}$ & Phase 3 & GlaxoSmithKline & Patients With BRAF-mutant melanoma & NCT01584648 \\
\hline $\begin{array}{l}\text { Vemurafenib (BRAF inhibitor) + } \\
\text { Cobimetinib (MEK inhibitor) }\end{array}$ & Phase 3 & Hoffmann-La Roche & Patients with metastatic melanoma & NCT01689519 \\
\hline $\begin{array}{l}\text { LGX818 (BRAF inhibitor) + } \\
\text { Binimetinib (MEK inhibitor) }\end{array}$ & Phase $1 \mathrm{~b} / 2$ & Novartis & Patients with BRAF mutant melanoma & NCT01909453 \\
\hline $\begin{array}{l}\text { Cobimetinib (MEK inhibitor) + } \\
\text { GDC-0994 (ERK inhibitor) }\end{array}$ & Phase 1 & Genentech, Inc. & $\begin{array}{l}\text { Patients with locally advanced or } \\
\text { metastatic solid tumors }\end{array}$ & NCT02457793 \\
\hline $\begin{array}{l}\text { Binimetinib (MEK inhibitor) + } \\
\text { BYL719 (PI3K inhibitor) }\end{array}$ & Phase $1 b$ & Array BioPharma & $\begin{array}{l}\text { Patients with selected advanced } \\
\text { solid tumors }\end{array}$ & NCT01449058 \\
\hline $\begin{array}{l}\text { Pimasertib ( MEK inhibitor) }+ \\
\text { SAR245409 (PI3K/mTOR inhibitor) }\end{array}$ & Phase 1 & EMD Serono & $\begin{array}{l}\text { Patients with locally advanced or } \\
\text { metastatic solid tumors }\end{array}$ & NCT01390818 \\
\hline $\begin{array}{l}\text { Pimasertib ( MEK inhibitor) + } \\
\text { SAR405838 (MDM2 antagonist) }\end{array}$ & Phase 1 & Sanofi & Patients with solid tumors & NCT01985191 \\
\hline $\begin{array}{l}\text { Binimetinib (MEK inhibitor) }+ \\
\text { LEE011 (CDK4/6 inhibitor) }\end{array}$ & Phase $1 \mathrm{~b} / 2$ & Array BioPharma & Patients with NRAS mutant melanoma & NCT01781572 \\
\hline $\begin{array}{l}\text { LGX818 (BRAF inhibitor) + } \\
\text { LEE011 (CDK4/6 inhibitor) }\end{array}$ & Phase 2 & Array BioPharma & Patients with advanced BRAF melanoma & NCT01820364 \\
\hline $\begin{array}{l}\text { Vemurafenib ( BRAF inhibitor) + } \\
\text { Palbociclib (PD-0332991) }\end{array}$ & Phase $1-2$ & $\begin{array}{l}\text { Assistance Publique - } \\
\text { Hôpitaux de Paris }\end{array}$ & Patients with metastatic melanoma & NCT02202200 \\
\hline $\begin{array}{l}\text { Anti- CTLA-4 (ipilimumab) + } \\
\text { anti-PD-1 (Nivolumab) }\end{array}$ & Phase 3 & Bristol-Myers Squibb & $\begin{array}{l}\text { Patients with untreated } \\
\text { advanced melanoma }\end{array}$ & NCT01844505 \\
\hline $\begin{array}{l}\text { Dabrafenib (BRAF inhibitor) + } \\
\text { anti- CTLA-4 (ipilimumab) +/- } \\
\text { Trametinib (MEK inhibitor) }\end{array}$ & Phase 1 & GlaxoSmithKline & $\begin{array}{l}\text { Patients with } \mathrm{V} 600 \mathrm{E} / \mathrm{K} \text { mutation positive } \\
\text { metastatic or unresectable melanoma }\end{array}$ & NCT01767454 \\
\hline $\begin{array}{l}\text { atezolizumab (anti-PD-L1 antibody) }+ \\
\text { Vemurafenib (BRAF inhibitor) }+/- \\
\text { Cobimetinib ( MEK inhibitor) }\end{array}$ & Phase 1 & Genentech, Inc. & $\begin{array}{c}\text { Patients with BRAFV600-mutation } \\
\text { positive metastatic melanoma }\end{array}$ & NCT01656642 \\
\hline $\begin{array}{l}\text { MK-3475 (Pembrolizumab) (anti-PD-1) } \\
+ \text { Dabrafenib (BRAF inhibitor)+ }\end{array}$ & Phase 1,2 & $\begin{array}{l}\text { Merck Sharp \& } \\
\text { Dohme Corp. }\end{array}$ & Patients with advanced melanoma & NCT02130466 \\
\hline $\begin{array}{l}\text { Trametinib (MEK inhbitor) } \\
\text { durvalumab (MEDI4736) (anti-PD-L1) } \\
\text { + Trametinib (MEK inhibitor) +/- } \\
\text { Dabrafenib (BRAF inhibitor) }\end{array}$ & Phase 1 & MedImmune LLC & $\begin{array}{l}\text { Patients with metastatic or } \\
\text { unresectable melanoma }\end{array}$ & NCT02027961 \\
\hline $\begin{array}{l}\text { Dabrafenib ( BRAF inhibitor)+ } \\
\text { Stereotactic Radiosurgery }\end{array}$ & Phase 2 & $\begin{array}{l}\text { University of California, } \\
\text { San Francisco }\end{array}$ & $\begin{array}{l}\text { Patients with BRAFV600E } \\
\text { melanoma brain metastases }\end{array}$ & NCT01721603 \\
\hline $\begin{array}{l}\text { Pembrolizumab) (anti-PD-1)+ } \\
\text { hypofractionated RT }\end{array}$ & Phase 1 & $\begin{array}{l}\text { Abramson Cancer Center } \\
\text { (University of Pennsylvania) }\end{array}$ & $\begin{array}{l}\text { Patients with advanced } \\
\text { and metastatic Cancers }\end{array}$ & NCT02303990 \\
\hline $\begin{array}{l}\text { Pembrolizumab) (anti-PD-1) + } \\
\text { Sterotactic Body Radiotherapy }\end{array}$ & Phase 1-2 & Yale University & $\begin{array}{l}\text { Patients with metastatic } \\
\text { melanoma or NSCLC }\end{array}$ & NCT02407171 \\
\hline
\end{tabular}

the genome, p53 protects cells from genetic assaults by triggering cell-cycle arrest and apoptosis. In many tumors, the TP53 gene itself is mutated disabling its tumor suppressor activity. In melanoma, p53 is mutated in only $17 \%$ of cutaneous melanoma and in $8-10 \%$ of acral and mucosal melanomas (4); but its function is frequently attenuated by a variety of mechanisms, including increased expression of MDM2 (41) and/or MDM4 (42). Additionally, p53 function is compromised by deletions in the CDKN2A locus, which inactivates both $\mathrm{p} 14^{\mathrm{ARF}}$ and $\mathrm{p} 16^{\mathrm{INK} 4 \mathrm{a}}$ in about $50 \%$ of melanomas (43). Increasing evidence supports a role for $\mathrm{p} 53$ in BRAF and NRAS driven melanoma progression in mice
$(44,45)$ and zebrafish (46). Thus, p53 represents an important therapeutic target for melanoma. In an effort to reactivate p53, two strategies have been employed (Figure 1).

The first involves increasing wild-type p53 levels by interfering with the MDM2/4 mediated proteasomal degradation of p53 using antagonists that inhibit MDM2/MDM4-p53 interactions. Combining the antagonist of the MDM2-p53 interaction, Nutlin3, with MAPK inhibitors suppresses melanoma growth and potentiates MAPK inhibition $(47,48)$. Restoring the apoptotic function of p53 by inhibiting MDM2 and iASPP cooperates with V600E BRAF inhibition to suppress human melanoma cell growth both in 
vitro and in vivo (49). Further, the combination of pimasertib (MEK inhibitor) with another antagonist of MDM2 (SAR405838) was investigated in phase I trial in patients with solid tumors (NCT01985191) (Table I). In cells where MDM2 is low, MDM4 could be the principle regulator of p53 (50). It has been shown that MDM4 is overexpressed in about $65 \%$ of human melanomas and that its inhibition by SAH-p53-8 affects the growth of melanoma cells that have acquired resistance to BRAF inhibitors and synergizes with BRAF inhibitors to kill BRAF mutant cells (50).

The second strategy used to re-activate p53, consists of targeting p53 directly using small molecules as PRIMA-1 (stands for "p53 Reactivation and Induction of Massive Apoptosis") and its methylated form PRIMA-1 ${ }^{\text {Met }}$ (APR246) that have the ability to convert mutant and wild-type inactive p53 to an active conformation, restoring DNA binding and transcriptional activity $(51,52)$. PRIMA1/PRIMA-1 ${ }^{\text {Met }}$ alone or in combination with chemotherapy has been shown to have good efficacy against various types of cancers, such as leukemia $(53)$, breast $(54,55)$, thyroid (56), pancreatic (57), ovarian (58), prostate (59), colorectal (60) and non-small lung cancers (61). The safety of APR246/PRIMA-1 ${ }^{\text {Met }}$ has recently been tested in a phase I clinical trial (62) and after positive data obtained from a clinical phase I/II study with APR-246, a global pivotal phase III study in high grade serous ovarian cancer (HGSOC) patients is also intended for PRIMA-1Met. In melanoma, we evaluated recently the potential of combining oncogenic BRAF inhibition with direct pharmacological reactivation of $\mathrm{p} 53$ (63). We found that the p53 activator (PRIMA-1 ${ }^{\text {Met }}$ ) synergized with the BRAF inhibitor vemurafenib to induce apoptosis and suppress proliferation in vitro and to inhibit tumor growth of BRAF mutated melanoma cells in vivo. Importantly, this drug combination decreased the viability of both vemurafenib-sensitive and resistant melanoma cells irrespectively of the p53 status. Thus, PRIMA-1 ${ }^{\text {Met }}$ through its ability to directly reactivate p53 regardless of the mechanism causing its deactivation, and thereby dampen PI3K signalling, sensitizes $\mathrm{V} 600 \mathrm{E} / \mathrm{K}_{\mathrm{BRAF}}$-positive melanoma to BRAF inhibitors. This work has also been the rationale for an academic phase I/II clinical trial using this original combination.

Nevertheless, the anti-melanoma potential of p53 reactivation was also evaluated in combination with a MEK inhibitor in NRAS mutant melanoma cells and our preliminary results demonstrate a strong synergistic effect of this combination (data not published).

Taken together, these data suggest that the combination of MAPK inhibitors with additional pharmacological agents like a p53 reactivator, converting their predominantly cytostatic to a cytotoxic effect, could improve their efficacy. Co-targeting $M A P K$ and $C D K / 4$. Cyclin-dependent kinases $(\mathrm{CDK})$ are a family of serine/threonine kinases that drive cycle progression, control transcriptional processes, DNA replication and cell division $(64,65)$. The synthesis of cyclins and their bindings to $\mathrm{CDK}$ are specific of the stages of the cell cycle and regulate CDK activity $(64,65)$. The activity of CDK is also regulated by the families of the inhibitory proteins of CDK including $\mathrm{p} 15, \mathrm{p} 16^{\mathrm{INK} 4 \mathrm{a}}, \mathrm{p} 18$, $\mathrm{p} 21$ and $\mathrm{p} 27$. The $\mathrm{p} 16^{\mathrm{INK} 4 \mathrm{a}}$ protein binds to CDK4/6 inhibiting interaction with cyclins $\mathrm{D}$, which would otherwise promote cell-cycle progression by inhibiting retinoblastoma (RB) protein $(64,65)$. The $\mathrm{p} 16 /$ cyclin $\mathrm{D} / \mathrm{CDK} 4 / 6 / \mathrm{RB}$ protein pathway (CDK4 pathway) is dysregulated in $90 \%$ of melanomas $(66,67)$. Furthermore, activation of the CDK4 pathway cooperates with mutant BRAF or NRAS in transformation of melanocytes $(68,69)$. MAPK pathway also enhances CDK4 signaling through increasing cyclin D1 expression. Amplification of cyclin D1 is detected in about $17 \%$ of BRAF V600E-mutated human metastatic melanomas, and, when it is combined with dysregulation of CDK4, it contributes to the resistance to BRAF inhibitor in such mutant melanoma cells (70). Thus, the emerging CDK4 as an important target in melanoma and other cancers led to the development of small-molecule inhibitors of the kinase activity of CDK4 (Figure 1). CDK4/6 inhibitors have been tested as single agents or in combination. Studies were focusing on evaluating the rational combination of CDK4/6 inhibitors with MAPK inhibitors (Table I). A study have demonstrated that dual inhibition of CDK2 and CDK4 enhanced response to BRAF and MEK inhibitors in melanoma cells in vitro and in vivo (71). Further, the combination of CDK4-inhibitor palbociclib with trametinib (MEK inhibitor) has shown a synergistic effect in NRASmutant melanoma (72). The CDK4/6 inhibitors palbociclib (PD-0332991) and ribociclib (LEE011) have been evaluated in several phase I-II trials in combination with MEK and BRAF inhibitors (NCT02065063, NCT02202200, NCT01777776, NCT01781572 and NCT01820364). The combination of the CDK4/6 inhibitor ribociclib (LEE011) with the MEK1/2 inhibitor binimetinib (MEK162) has also shown an activity in patients with NRAS mutant melanoma (NCT01719380). The activity of CDK4/6 inhibitors appears to be greater where there is higher activity of CDK4 pathway (mutant or amplified CDK4, gains of cyclin D1) and inactivation of $\mathrm{RB}$ protein appears to predict resistance to CDK4 and CDK6 inhibitors (73).

\section{Multimodality Treatments and Future Directions}

Immunotherapy and targeted-therapy combinations. Another modality in melanoma treatment involves the use of immunotherapy. The immune checkpoint inhibitors, anti CTLA-4 (ipilimumab) and anti-PD1/PDL1 antibodies (pembrolizumab, lambrolizumab, nivolumab, MPDL3280) (Figure 2) have made revolutionary immunotherapeutic 
advances and have demonstrated clinical activity in melanoma $(23,74-78)$. In addition to their use as monotherapies, anti-CTLA-4 and anti-PD1/PDL1 are now being combined in clinical trials, and have shown impressive response rates (Table I). Indeed, concurrent or sequential combination of anti-CTLA-4 and anti-PD-1 achieved an objective response rate (ORR) of $40 \%$ (ranging from 21 to $53 \%, \mathrm{n}=52$ ). Further, $31 \%$ of the patients treated with the concomitant combination had a reduction in disease burden of at least $80 \%$ (NCT01024231).

The discovery of either molecularly effective targeted therapies or immunotherapies has led to dramatic improvements to the standard-of-care treatment of melanoma. Treatment with targeted therapy yields rapid but non-durable responses in most patients. Conversely, treatment with immune checkpoint blockade can produce durable but often delayed responses. Thus, dual immune and molecular therapy together can lead to early and robust antitumor responses with long-term benefit for patients.

Targeted therapy affects antitumor immunity, and synergy may exist when targeted therapy is combined with immunotherapy (Figure 2). Indeed, it was suggested that oncogenic BRAF can lead to a tumoral immune escape (79, 80). Furthermore, treatment with MAPK inhibitors is associated with enhanced expression of melanocytic antigens, antigen recognition by $\mathrm{T}$ cells, and influx of cytotoxic $\mathrm{T}$ lymphocytes (CTLs) (81-83). Also, it was suggested that resistance to BRAF inhibitor leads to increased expression of PD-L1 in melanoma cells, and MEK inhibition shows dual therapeutic effects with simultaneous suppression of PD-L1 expression and induction of apoptosis (84). These findings offer compelling evidence for the development of combined targeted and immune therapies, and indicate immune checkpoint blockade may enhance antitumoral response when combined with MAPK inhibition. An ongoing targeted and immunotherapy trial uses dabrafenib with or without trametinib combined with ipilimumab in patients with BRAF V600E/K-mutated metastatic melanoma (NCT01767454). Other clinical studies have been planned or are underway (Table I), each with varying dose levels and schedules of combination therapy administration (NCT01656642, NCT02130466 and NCT02027961). These trials will help in understanding the profile of toxicity, the optimal timing and sequence of the combination therapy profile. It will also provide preliminary efficacy data of various combinations and will help to guide optimal management of melanoma patients.

Combining MAPK inhibition and radiotherapy. Melanoma is commonly regarded as a radioresistant tumor entity, although adjuvant radiotherapy plays a role in treatment regimens for patients suffering from advanced disease by reducing the risk of local and metastatic tumor relapse (76). Moreover, radiation therapy is often used to relieve symptoms caused by the spread of the melanoma, especially to the brain or bones. Radiation, like a variety of other cellular stress factors, can activate or down-regulate multiple signaling pathways, leading to either increased cell death or increased cell proliferation. Modulation of the signaling process however, depends on the cell type, radiation dose, and culture conditions (85). MAPK signaling is known to potentially influence tumor cell radiosensitivity because of their activity associated with radiation-induced DNA damage response.

ERK is activated very rapidly in tumor cells in response to radiation (86). Mutations occurring in the RAS/RAF pathway further result in enhanced tumor cell proliferation and survival after irradiation $(87,88)$.

Interestingly, inhibition of BRAF in melanoma brain metastasis with activating BRAF mutations results in sensitization to ionizing radiation $(89,90)$. The combination of BRAF inhibitor dabrafenib with stereotactic radiosurgery in ${ }^{\mathrm{V} 600 \mathrm{E}} \mathrm{BRAF}$ melanoma brain metastases is investigated in a phase 2 prospective trial (NCT01721603).

The MEK inhibitor trametinib radiosensitizes RAS-/RAFmutated melanoma cells by inducing prolonged G1 arrest and premature senescence. In this pre-clinical study Schick et al. demonstrated that combining trametinib and radiotherapy is well tolerated and reduces tumor growth in vivo (91).

Furthermore, Eder $\mathrm{S}$ et al. (92) have shown that pharmacological interference with MAPK signaling increases vulnerability of NRAS-mutant melanoma cells to ionizing radiation and point towards a possible use for combined MEK inhibition and localized radiation therapy of malignant melanoma in the NRAS-mutant setting where BRAF inhibitors offer no clinical benefit. Additionally, RTKi potentiate the effect of radiotherapy in cancer (93). These observations suggest that signaling through the MAPK pathway is important in radiation response and radiation resistance, and inhibition of this cascade may be an attractive means to sensitize tumor cells to ionizing radiation.

Regarding the rationale behind combined targeted therapy and immunotherapy and given the potential synergy between radiotherapy and targeted therapy on one hand and immunotherapy on the other, adding radiotherapy to the dual therapies (imuno- and targeted- therapies) could also be an option that may lead to improvements in locoregional and distant tumor control and would be effective in the cases of brain metastasis.

$P 53$ reactivation and radiotherapy. $\mathrm{P} 53$ pathway is known to be implicated in the regulation of the response to ionizing radiations in tumor cells (94-96). Radiation will induce ataxia telangiectasia (ATM) mutated and other kinases that results in the phosphorylation and activation of p53 (Figure 2) (97).

Several studies have reported synergistic suppressive effects of combining TP53 gene transfer treatment with $\mathrm{x}-$ ray radiation on various cancer cells including head and 


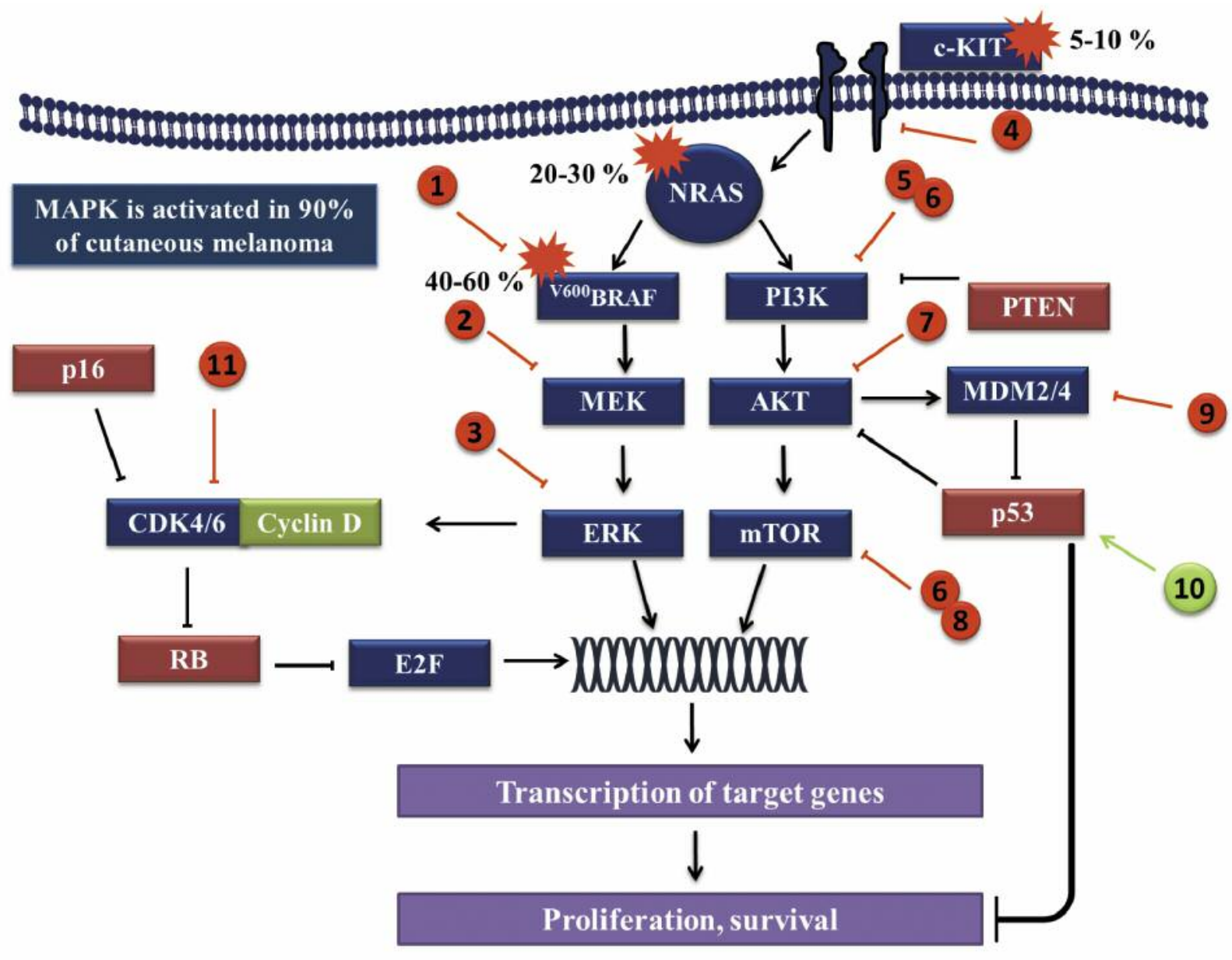

BRAF inhibitors ( vemurafenib, dabrafenib...)

2. MEK inhibitors ( trametinib, pimasetib, binimetinib, cobimetinib...)

(3) ERK inhibitors (SCH772984, GDC-0994 ...)

(4) c-KIT inhibitors ( dasatinib, sunitinib, imatinib...)

(5) PI3K inhibitors ( XL147, BKM120, GDC0941...)

6 Dual PI3K/mTOR inhibitors (BEZ235, XL765, SAR245409... )
AKT inhibitors (MK2206, GSK690693...)

8 mTOR inhibitors (everolimus, temsirolimus...)

(9) MDM2 inhibitors (SAR405838, RG7112...)

MDM4 inhibitors (SAH-p53-8...)

10) P53 activators (PRIMA-1 Met $^{\text {Met }}$ (APR-246) ...)

11 CDK4/6 inhibitors (palbociclib, ribociclib (LEE011) ...)

Mutation

Figure 1. Key melanoma signaling pathways involved in proliferation and survival and selected therapeutic agents that target each of these pathways. MAPK pathway is the central pathway in melanoma, activated in nearly $90 \%$ of cases due to oncogenic mutations in c-KIT, NRAS and BRAF. In parallel, PI3K/AKT pathway is also activated in melanoma due to loss of function of PTEN or activation of AKT. The pro-apoptotic p53 pathway is inactivated in the majority of the cases in melanoma due to overexpression of its negative regulators (MDM2/MDM4). The p16/cyclin D/CDK4/6 - retinoblastoma protein (RB1) pathway (CDK4 pathway) is also dysregulated in melanoma. Numbers in the red circles (1-9, 11) and green circle (10) represent respectively the mechanism of action of inhibitors and activators used to modulate these pathways with a high therapeutic potential. 


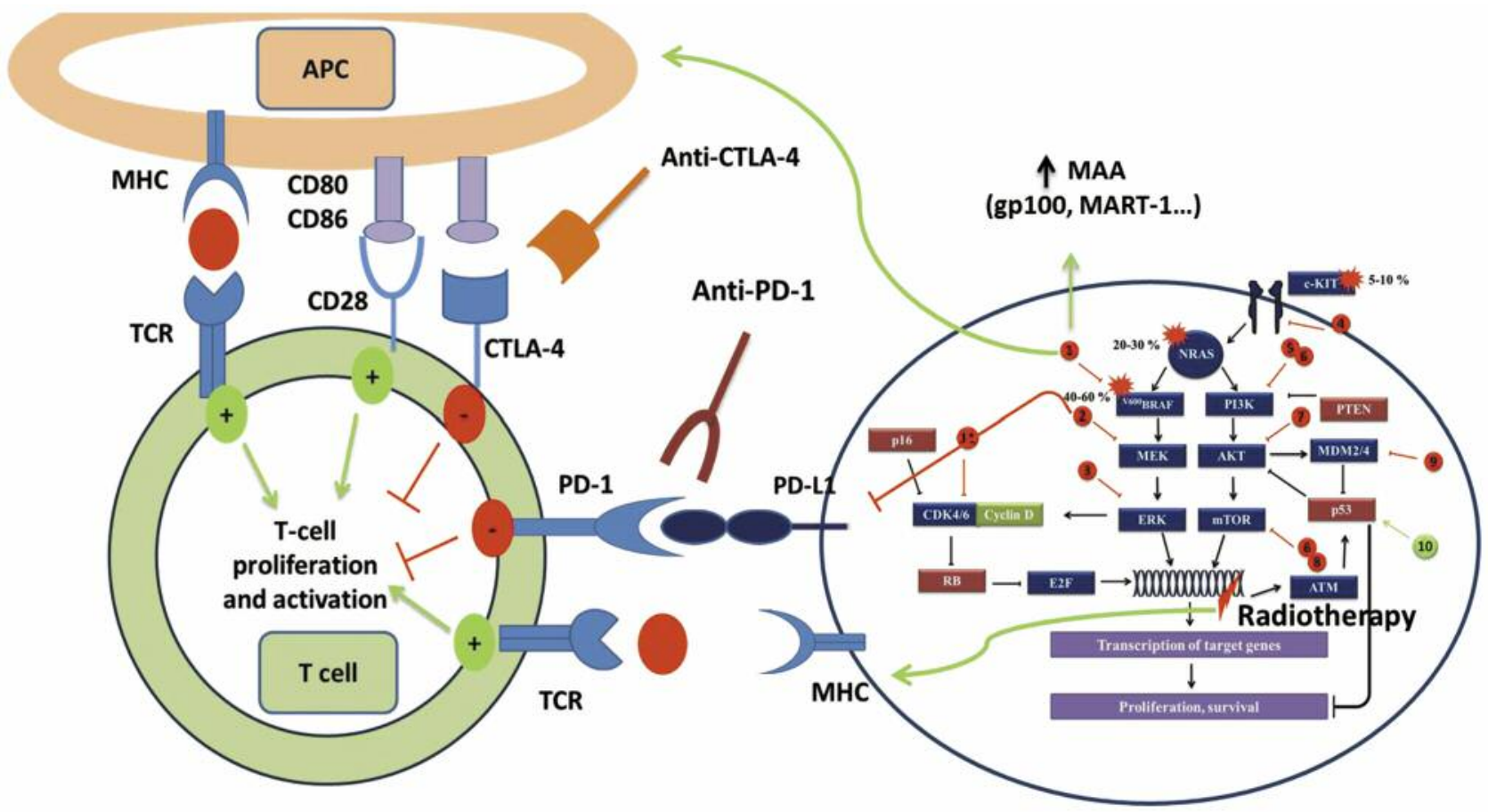

Figure 2. Multimodality treatments and future directions. Schematic representation of the main reasons behind the rationale to use combinatorial approaches including targeted therapies, immunotherapy and radiotherapy. New immunotherapeutic agents in melanoma involve immune checkpoint inhibitors anti-CTLA-4 and anti-PD1/PDL1 antibodies. (A) Upon T cell activation via T cell receptor (TCR) engagement by MHC-peptide complex between APC and T cells, CTLA-4 competitively blocks the binding of costimulatory ligands CD80 and CD86 to CD28. Antibodies against CTLA4 (ipilimumab) act at the initiation of the immune response by maintaining T cell activation. $(B)$ In metastatic melanoma, the interaction of PD-L1 expressed by melanoma cells with PD-1 induces $T$ cell suppression. Anti-PD-1 antibodies induce T cell reactivation by preventing binding of PD-1 with its ligands. (C) Activation of dendritic cells and up-regulation of MAA (melanoma associated antigens) by BRAF inhibition and suppression of PD-L1 expression by MEK inhibition offer compelling rationale to combine targeted and immune therapies. (D) Radiotherapy can induce the activation of p53 via ATM. Targeting MAPK and p53 can sensitize melanoma cells to radiation. (E) Radiotherapy combined with anti-PD-L1 upregulates MHC, and increases tumor cell susceptibility to immune-mediated cell death.

neck, glioblastoma, colorectal, cervical, lung, and malignant glioma cell lines (98-103). In murine melanoma cells, Duan X. et al. (104) found that heavy-ion radiation combined with TP53 gene transfer induced apoptosis. Furthermore, the effects of wild type p53 activation via MDM2 inhibition in combination with radiation have been examined in lung and prostate cancers $(95,105,106)$. Recently, a study by Feng F. et al. (107) showed that MDM2 inhibition combined with MI-219 results in p53dependent sensitization of prostate cancer cells to radiation. Another study by William J. et al. (108) reported that intrinsic radiosensitivity of 39 human tumor cell lines segregated into distinct genotype-dependent radiosensitivity groups that are associated with wild-type TP53 and mutant TP53, showing that wild-type TP53 cells are significantly more sensitive than mutated ones.

Unfortunately, only a few observations are available for the impact of p53 targeting on radiotherapy in melanoma.
Immunotherapy and radiotherapy combination. Investigations into the interaction between radiotherapy and the host immune system have elucidated new mechanisms that can potentially be exploited to improve the efficacy of radiotherapy (109).

The combination of local radiotherapy and immunemodulation can augment local tumor control and cause distant antitumor effects (abscopal), increasing tumor-antigen release and antigen-presenting cell (APC) cross-presentation, improving dendritic cell (DC) function, and enhancing T cell priming (110-113) (Figure 2). On the other hand, ionizing radiation can also generate chemotactic signals that recruit several myeloid-cell types with distinct roles in $\mathrm{T}$ cell suppression (114-116).

The major clinical successes in the nascent field of radioimmunomodulation are the result of the advent of immunecheckpoint inhibitors. Inhibitors of the CTLA-4 pathway, such as ipilimumab, have shown encouraging results in the treatment of patients with cancer. CTLA-4 functions as an immunosuppressor 
by increasing the signal intensity required for $\mathrm{CD}^{+} \mathrm{T}$ cells to engage target cells in the tumors (117).

A retrospective study where patients with advanced melanoma were grouped into those who had received concurrent radiotherapy while on ipilimumab (Ipi-RT), and those who did not, showed an improved survival and complete response rates in patients treated with concurrent ipilimumab and radiotherapy versus ipilimumab alone. Also, toxicities were not increased in the Ipi-RT group compared with ipilimumab alone (118).

In addition, inhibition of the PD-1/PD-L1 pathway on $\mathrm{T}$ cells has been associated with a potent antitumor activity in mouse tumor models and in clinical trials (71, 115-117).

A preliminary preclinical report has indicated that radiotherapy combined with anti-PD-1 antibody treatment can result in primary tumor control (119). More recent data from the same group indicated that this therapy combination results in induction of endogenous antigen-specific immune responses, resulting in improved local control in single tumor models of melanoma or breast carcinoma (112).

Thus, current evidence indicates that enhancing innate and adaptive immunity by combining radiotherapy and immunotherapy is a crucial strategy to improve patient survival.

\section{Conclusion}

Melanoma treatment has witnessed dramatic progress and several revolutionary therapeutic advances with the discovery of molecularly-effective targeted therapies (BRAF and MEK inhibitors) and immunotherapies (anti-CTLA-4 and anti-PD1/PDL1 antibodies) which significantly improve the standard-of-care treatment of melanoma. Monotherapy is unlikely to yield a long-term benefit due to drug resistance. Thus, rationale-based combinatorial strategies are the key to overcome resistance and obtain a long-term response. Ongoing studies are investigating many combinatorial approaches but the key issues addressed are the ideal timing and sequences of combination regimens that can give the higher efficacy, durable response and lower toxicity.

\section{Conflicts of Interest}

The Authors declare no conflicts of interest.

\section{Acknowledgements}

This work has been supported by a grant from "Les Amis de l'Institut J. Bordet" and "Fondation contre le Cancer", Belgium. AN was a recipient of the "BRIC" grant, Université Libre de Bruxelles.

\section{References}

1 Jemal A, Siegel R, Xu J and Ward E: Cancer statistics, 2010. CA Cancer J Clin 60: 277-300, 2010.
2 Shoo BA and Kashani-Sabet M: Melanoma arising in African-, Asian-, Latino- and Native-American populations. Semin Cutan Med Surg 28: 96-102, 2009.

3 Davies H, Bignell GR, Cox C, Stephens P, Edkins S, Clegg S, Teague J, Woffendin H, Garnett MJ, Bottomley W, Davis N, Dicks E, Ewing R, Floyd Y, Gray K, Hall S, Hawes R, Hughes J, Kosmidou V, Menzies A, Mould C, Parker A, Stevens C, Watt S, Hooper S, Wilson R, Jayatilake H, Gusterson BA, Cooper C, Shipley J, Hargrave D, Pritchard-Jones K, Maitland N, ChenevixTrench G, Riggins GJ, Bigner DD, Palmieri G, Cossu A, Flanagan A, Nicholson A, Ho JWC, Leung SY, Yuen ST, Weber BL, Seigler HF, Darrow TL, Paterson H, Marais R, Marshall CJ, Wooster R, Stratton MR and Futreal PA: Mutations of the BRAF gene in human cancer. Nature 417: 949-954, 2002.

4 Siroy AE, Boland GM, Milton DR, Roszik J, Frankian S, Malke J, Haydu L, Prieto VG, Tetzlaff M, Ivan D, Wang W-L, TorresCabala C, Curry J, Roy-Chowdhuri S, Broaddus R, Rashid A, Stewart J, Gershenwald JE, Amaria RN, Patel SP, Papadopoulos NE, Bedikian A, Hwu W-J, Hwu P, Diab A, Woodman SE, Aldape KD, Luthra R, Patel KP, Shaw KR, Mills GB, Mendelsohn J, Meric-Bernstam F, Kim KB, Routbort MJ, Lazar AJ and Davies MA: Beyond BRAF(V600): clinical mutation panel testing by next-generation sequencing in advanced melanoma. J Invest Dermatol 135: 508-515, 2015.

5 Chapman PB, Hauschild A, Robert C, Haanen JB, Ascierto P, Larkin J, Dummer R, Garbe C, Testori A, Maio M, Hogg D, Lorigan P, Lebbe C, Jouary T, Schadendorf D, Ribas A, O'Day SJ, Sosman JA, Kirkwood JM, Eggermont AMM, Dreno B, Nolop K, Li J, Nelson B, Hou J, Lee RJ, Flaherty KT, McArthur GA and BRIM-3 Study Group: Improved survival with vemurafenib in melanoma with BRAF V600E mutation. N Engl J Med 364: 2507-2516, 2011.

6 Flaherty KT, Robert C, Hersey P, Nathan P, Garbe C, Milhem M, Demidov LV, Hassel JC, Rutkowski P, Mohr P, Dummer R, Trefzer U, Larkin JMG, Utikal J, Dreno B, Nyakas M, Middleton MR, Becker JC, Casey M, Sherman LJ, Wu FS, Ouellet D, Martin A-M, Patel K, Schadendorf D and METRIC Study Group: Improved survival with MEK inhibition in BRAF-mutated melanoma. N Engl J Med 367: 107-114, 2012.

7 Hodi FS, Corless CL, Giobbie-Hurder A, Fletcher JA, Zhu M, Marino-Enriquez A, Friedlander P, Gonzalez R, Weber JS, Gajewski TF, O’Day SJ, Kim KB, Lawrence D, Flaherty KT, Luke JJ, Collichio FA, Ernstoff MS, Heinrich MC, Beadling C, Zukotynski KA, Yap JT, Van den Abbeele AD, Demetri GD and Fisher DE: Imatinib for melanomas harboring mutationally activated or amplified KIT arising on mucosal, acral, and chronically sun-damaged skin. J Clin Oncol Off J Am Soc Clin Oncol 31: 3182-3190, 2013.

8 Bollag G, Tsai J, Zhang J, Zhang C, Ibrahim P, Nolop K and Hirth P: Vemurafenib: the first drug approved for BRAF-mutant cancer. Nat Rev Drug Discov 11: 873-886, 2012.

9 Hauschild A, Grob J-J, Demidov LV, Jouary T, Gutzmer R, Millward M, Rutkowski P, Blank CU, Miller WH, Kaempgen E, Martín-Algarra S, Karaszewska B, Mauch C, Chiarion-Sileni V, Martin A-M, Swann S, Haney P, Mirakhur B, Guckert ME, Goodman V and Chapman PB: Dabrafenib in BRAF-mutated metastatic melanoma: a multicentre, open-label, phase 3 randomised controlled trial. Lancet 380: 358-365, 2012.

10 Houede N, Faivre SJ, Awada A, Raymond E, Italiano A, BesseHammer T, Donica M, Rejeb N, Luepfert C, Ongarello S and 
Delord J: Safety and evidence of activity of MSC1936369, an oral MEK1/2 inhibitor, in patients with advanced malignancies. J Clin Oncol 29: 2011 (suppl; abstr 3019), 2011.

11 Ascierto PA, Schadendorf D, Berking C, Agarwala SS, van Herpen CM, Queirolo P, Blank CU, Hauschild A, Beck JT, StPierre A, Niazi F, Wandel S, Peters M, Zubel A and Dummer R: MEK162 for patients with advanced melanoma harbouring NRAS or Val600 BRAF mutations: a non-randomised, openlabel phase 2 study. Lancet Oncol 14: 249-256, 2013.

12 Delord J, Houede N, Awada A, Taamma A, Faivre SJ, BesseHammer T, Italiano A, Vignaud C, Donica M and Raymond E: First-in-human phase I safety, pharmacokinetic (PK), and pharmacodynamic (PD) analysis of the oral MEK-inhibitor AS703026 (two regimens [R]) in patients (pts) with advanced solid tumors. J Clin Oncol 28: 15s, 2010.

13 Buchbinder EI, Sosman JA, Lawrence DP, McDermott DF, Ramaiya NH, Van den Abbeele AD, Linette GP, GiobbieHurder A and Hodi FS: Phase 2 study of sunitinib in patients with metastatic mucosal or acral melanoma. Cancer 121: 40074015, 2015.

14 Alcalá AM and Flaherty KT: BRAF inhibitors for the treatment of metastatic melanoma: clinical trials and mechanisms of resistance. Clin Cancer Res Off J Am Assoc Cancer Res 18: 3339, 2012.

15 Shi H, Hugo W, Kong X, Hong A, Koya RC, Moriceau G, Chodon T, Guo R, Johnson DB, Dahlman KB, Kelley MC, Kefford RF, Chmielowski B, Glaspy JA, Sosman JA, van Baren N, Long GV, Ribas A and Lo RS: Acquired resistance and clonal evolution in melanoma during BRAF inhibitor therapy. Cancer Discov 4: 80-93, 2014.

16 Rizos H, Menzies AM, Pupo GM, Carlino MS, Fung C, Hyman J, Haydu LE, Mijatov B, Becker TM, Boyd SC, Howle J, Saw R, Thompson JF, Kefford RF, Scolyer RA and Long GV: BRAF inhibitor resistance mechanisms in metastatic melanoma: spectrum and clinical impact. Clin Cancer Res Off J Am Assoc Cancer Res 20: 1965-1977, 2014.

17 Heidorn SJ, Milagre C, Whittaker S, Nourry A, NiculescuDuvas I, Dhomen N, Hussain J, Reis-Filho JS, Springer CJ, Pritchard C and Marais R: Kinase-dead BRAF and oncogenic RAS cooperate to drive tumor progression through CRAF. Cell 140: 209-221, 2010.

18 Oberholzer PA, Kee D, Dziunycz P, Sucker A, Kamsukom N, Jones R, Roden C, Chalk CJ, Ardlie K, Palescandolo E, Piris A, MacConaill LE, Robert C, Hofbauer GFL, McArthur GA, Schadendorf D and Garraway LA: RAS mutations are associated with the development of cutaneous squamous cell tumors in patients treated with RAF inhibitors. J Clin Oncol Off J Am Soc Clin Oncol 30: 316-321, 2012.

19 Hatzivassiliou G, Song K, Yen I, Brandhuber BJ, Anderson DJ, Alvarado R, Ludlam MJC, Stokoe D, Gloor SL, Vigers G, Morales T, Aliagas I, Liu B, Sideris S, Hoeflich KP, Jaiswal BS, Seshagiri S, Koeppen H, Belvin M, Friedman LS and Malek S: RAF inhibitors prime wild-type RAF to activate the MAPK pathway and enhance growth. Nature 464: 431-435, 2010.

20 Krayem M, Journe F, Wiedig M, Morandini R, Sales F, Awada A and Ghanem G: Prominent role of cyclic adenosine monophosphate signalling pathway in the sensitivity of (WT)BRAF/(WT)NRAS melanoma cells to vemurafenib. Eur J Cancer Oxf Engl 1990 50: 1310-1320, 2014.
21 Flaherty KT, Infante JR, Daud A, Gonzalez R, Kefford RF, Sosman J, Hamid O, Schuchter L, Cebon J, Ibrahim N, Kudchadkar R, Burris HAI, Falchook G, Algazi A, Lewis K, Long GV, Puzanov I, Lebowitz P, Singh A, Little S, Sun P, Allred A, Ouellet D, Kim KB, Patel K and Weber J: Combined BRAF and MEK Inhibition in Melanoma with BRAF V600 Mutations. N Engl J Med 367: 1694-1703, 2012.

22 Polkowska M, Czepielewska E and Kozłowska-Wojciechowska M: Drug Combinations as the New Standard for Melanoma Treatment. Curr Treat Options Oncol 17: 61, 2016.

23 Hutchinson L: Melanoma: Therapy combinations: celebrating more milestones. Nat Rev Clin Oncol 12: 685-685, 2015.

24 Long GV, Stroyakovskiy D, Gogas H, Levchenko E, de Braud F, Larkin J, Garbe C, Jouary T, Hauschild A, Grob JJ, Chiarion Sileni V, Lebbe C, Mandalà M, Millward M, Arance A, Bondarenko I, Haanen JBAG, Hansson J, Utikal J, Ferraresi V, Kovalenko N, Mohr P, Probachai V, Schadendorf D, Nathan P, Robert C, Ribas A, DeMarini DJ, Irani JG, Casey M, Ouellet D, Martin A-M, Le N, Patel K and Flaherty K: Combined BRAF and MEK inhibition versus BRAF inhibition alone in melanoma. N Engl J Med 371: 1877-1888, 2014.

25 Larkin J, Ascierto PA, Dréno B, Atkinson V, Liszkay G, Maio M, Mandalà M, Demidov L, Stroyakovskiy D, Thomas L, de la Cruz-Merino L, Dutriaux C, Garbe C, Sovak MA, Chang I, Choong N, Hack SP, McArthur GA and Ribas A: Combined Vemurafenib and Cobimetinib in BRAF-Mutated Melanoma. N Engl J Med 371: 1867-1876, 2014.

26 Medina TM and Lewis KD: The evolution of combined molecular targeted therapies to advance the therapeutic efficacy in melanoma: a highlight of vemurafenib and cobimetinib. OncoTargets Ther 9: 3739-3752, 2016.

27 Atefi M, Titz B, Avramis E, Ng C, Wong DJ, Lassen A, Cerniglia M, Escuin-Ordinas H, Foulad D, Comin-Anduix B, Graeber TG and Ribas A: Combination of pan-RAF and MEK inhibitors in NRAS mutant melanoma. Mol Cancer 14: 27, 2015.

28 Wong DJ, Robert L, Atefi MS, Lassen A, Avarappatt G, Cerniglia M, Avramis E, Tsoi J, Foulad D, Graeber TG, CominAnduix B, Samatar A, Lo RS and Ribas A: Antitumor activity of the ERK inhibitor SCH722984 against BRAF mutant, NRAS mutant and wild-type melanoma. Mol Cancer 13, 2014.

29 Jiang X, Zhou J, Yuen NK, Corless CL, Heinrich MC, Fletcher JA, Demetri GD, Widlund HR, Fisher DE and Hodi FS: Imatinib targeting of KIT-mutant oncoprotein in melanoma. Clin Cancer Res Off J Am Assoc Cancer Res 14: 7726-7732, 2008.

30 Kelleher FC and McArthur GA: Targeting NRAS in melanoma. Cancer J Sudbury Mass 18: 132-136, 2012.

31 Krayem M, Journe F, Wiedig M, Morandini R, Najem A, Salès F, van Kempen LC, Sibille C, Awada A, Marine J-C and Ghanem G: p53 Reactivation by PRIMA-1(Met) (APR-246) sensitises (V600E/K)BRAF melanoma to vemurafenib. Eur J Cancer Oxf Engl 1990 55: 98-110, 2016.

32 Shi H, Hong A, Kong X, Koya RC, Song C, Moriceau G, Hugo W, Yu CC, Ng C, Chodon T, Scolyer RA, Kefford RF, Ribas A, Long GV and Lo RS: A novel AKT1 mutant amplifies an adaptive melanoma response to BRAF inhibition. Cancer Discov 4: 69-79, 2014.

33 Van Allen EM, Wagle N, Sucker A, Treacy DJ, Johannessen CM, Goetz EM, Place CS, Taylor-Weiner A, Whittaker S, Kryukov GV, Hodis E, Rosenberg M, McKenna A, Cibulskis K, Farlow D, 
Zimmer L, Hillen U, Gutzmer R, Goldinger SM, Ugurel S, Gogas HJ, Egberts F, Berking C, Trefzer U, Loquai C, Weide B, Hassel JC, Gabriel SB, Carter SL, Getz G, Garraway LA, Schadendorf D and Dermatologic Cooperative Oncology Group of Germany (DeCOG): The genetic landscape of clinical resistance to RAF inhibition in metastatic melanoma. Cancer Discov 4: 94-109, 2014.

34 Rizos H, Menzies AM, Pupo GM, Carlino MS, Fung C, Hyman J, Haydu LE, Mijatov B, Becker TM, Boyd SC, Howle J, Saw R, Thompson JF, Kefford RF, Scolyer RA and Long GV: BRAF inhibitor resistance mechanisms in metastatic melanoma: spectrum and clinical impact. Clin Cancer Res Off J Am Assoc Cancer Res 20: 1965-1977, 2014.

35 Trunzer K, Pavlick AC, Schuchter L, Gonzalez R, McArthur GA, Hutson TE, Moschos SJ, Flaherty KT, Kim KB, Weber JS, Hersey P, Long GV, Lawrence D, Ott PA, Amaravadi RK, Lewis KD, Puzanov I, Lo RS, Koehler A, Kockx M, Spleiss O, Schell-Steven A, Gilbert HN, Cockey L, Bollag G, Lee RJ, Joe AK, Sosman JA and Ribas A: Pharmacodynamic effects and mechanisms of resistance to vemurafenib in patients with metastatic melanoma. J Clin Oncol Off J Am Soc Clin Oncol 31: 1767-1774, 2013.

36 Paraiso KHT, Xiang Y, Rebecca VW, Abel EV, Chen YA, Munko AC, Wood E, Fedorenko IV, Sondak VK, Anderson ARA, Ribas A, Palma MD, Nathanson KL, Koomen JM, Messina JL and Smalley KSM: PTEN loss confers BRAF inhibitor resistance to melanoma cells through the suppression of BIM expression. Cancer Res 71: 2750-2760, 2011.

37 Nathanson KL, Martin A-M, Wubbenhorst B, Greshock J, Letrero R, D'Andrea K, O'Day S, Infante JR, Falchook GS, Arkenau H-T, Millward M, Brown MP, Pavlick A, Davies MA, Ma B, Gagnon R, Curtis M, Lebowitz PF, Kefford R and Long GV: Tumor genetic analyses of patients with metastatic melanoma treated with the BRAF inhibitor dabrafenib (GSK2118436). Clin Cancer Res Off J Am Assoc Cancer Res 19: 4868-4878, 2013.

38 Aftimos PG, Wiedig M, Langouo Fontsa M, Awada A, Ghanem $G$ and Journe F: Sequential use of protein kinase inhibitors potentiates their toxicity to melanoma cells: a rationale to combine targeted drugs based on protein expression inhibition profiles. Int J Oncol 43: 919-926, 2013.

39 Lassen A, Atefi M, Robert L, Wong DJ, Cerniglia M, CominAnduix B and Ribas A: Effects of AKT inhibitor therapy in response and resistance to BRAF inhibition in melanoma. Mol Cancer 13: 83, 2014.

40 Posch C, Moslehi H, Feeney L, Green GA, Ebaee A, Feichtenschlager V, Chong K, Peng L, Dimon MT, Phillips T, Daud AI, McCalmont TH, LeBoit PE and Ortiz-Urda S: Combined targeting of MEK and PI3K/mTOR effector pathways is necessary to effectively inhibit NRAS mutant melanoma in vitro and in vivo. Proc Natl Acad Sci USA 110: 4015-4020, 2013.

41 Momand J, Zambetti GP, Olson DC, George D and Levine AJ: The mdm-2 oncogene product forms a complex with the p53 protein and inhibits p53-mediated transactivation. Cell 69: 1237-1245, 1992.

42 Marine J-CW, Dyer MA and Jochemsen AG: MDMX: from bench to bedside. J Cell Sci 120: 371-378, 2007.

43 Curtin JA, Fridlyand J, Kageshita T, Patel HN, Busam KJ, Kutzner H, Cho K-H, Aiba S, Bröcker E-B, LeBoit PE, Pinkel $\mathrm{D}$ and Bastian BC: Distinct sets of genetic alterations in melanoma. N Engl J Med 353: 2135-2147, 2005.
44 Goel VK, Ibrahim N, Jiang G, Singhal M, Fee S, Flotte T, Westmoreland S, Haluska FS, Hinds PW and Haluska FG: Melanocytic nevus-like hyperplasia and melanoma in transgenic BRAFV600E mice. Oncogene 28: 2289-2298, 2009.

45 Bardeesy N, Bastian BC, Hezel A, Pinkel D, DePinho RA and Chin L: Dual inactivation of RB and p53 pathways in RASinduced melanomas. Mol Cell Biol 21: 2144-2153, 2001.

46 Dovey M, White RM and Zon LI: Oncogenic NRAS cooperates with p53 loss to generate melanoma in zebrafish. Zebrafish 6 : 397-404, 2009.

47 Ji Z, Njauw CN, Taylor M, Neel V, Flaherty KT and Tsao H: p53 rescue through HDM2 antagonism suppresses melanoma growth and potentiates MEK inhibition. J Invest Dermatol 132: 356-364, 2012.

48 Ji Z, Kumar R, Taylor M, Rajadurai A, Marzuka-Alcalá A, Chen YE, Njauw C-NJ, Flaherty K, Jönsson G and Tsao H: Vemurafenib synergizes with nutlin-3 to deplete survivin and suppresses melanoma viability and tumor growth. Clin Cancer Res Off J Am Assoc Cancer Res 19: 4383-4391, 2013.

$49 \mathrm{Lu} \mathrm{M}$, Breyssens H, Salter V, Zhong S, Hu Y, Baer C, Ratnayaka I, Sullivan A, Brown NR, Endicott J, Knapp S, Kessler BM, Middleton MR, Siebold C, Jones EY, Sviderskaya EV, Cebon J, John T, Caballero OL, Goding CR and Lu X: Restoring 553 function in human melanoma cells by inhibiting MDM2 and cyclin B1/CDK1-phosphorylated nuclear iASPP. Cancer Cell 23: 618-633, 2013.

50 Gembarska A, Luciani F, Fedele C, Russell EA, Dewaele M, Villar S, Zwolinska A, Haupt S, de Lange J, Yip D, Goydos J, Haigh JJ, Haupt Y, Larue L, Jochemsen A, Shi H, Moriceau G, Lo RS, Ghanem G, Shackleton M, Bernal F and Marine J-C: MDM4 is a key therapeutic target in cutaneous melanoma. Nat Med 18: 1239-1247, 2012.

51 Bao W, Chen M, Zhao X, Kumar R, Spinnler C, Thullberg M, Issaeva N, Selivanova G and Strömblad S: PRIMA-1Met/APR246 induces wild-type p53-dependent suppression of malignant melanoma tumor growth in 3D culture and in vivo. Cell Cycle Georget Tex 10: 301-307, 2011.

52 Bykov VJN and Wiman KG: Mutant p53 reactivation by small molecules makes its way to the clinic. FEBS Lett 588: 2622-2627, 2014.

53 Nahi H, Merup M, Lehmann S, Bengtzen S, Möllgård L, Selivanova G, Wiman KG and Paul C: PRIMA-1 induces apoptosis in acute myeloid leukaemia cells with p53 gene deletion. Br J Haematol 132: 230-236, 2006.

54 Russo D, Ottaggio L, Penna I, Foggetti G, Fronza G, Inga A and Menichini P: PRIMA-1 cytotoxicity correlates with nucleolar localization and degradation of mutant p53 in breast cancer cells. Biochem Biophys Res Commun 402: 345-350, 2010.

55 Synnott NC, Murray A, McGowan PM, Kiely M, Kiely PA, O'Donovan N, O'Connor DP, Gallagher WM, Crown J and Duffy MJ: Mutant p53: a novel target for the treatment of patients with triple-negative breast cancer? Int J Cancer 140: 234-246, 2017.

56 Messina RL, Sanfilippo M, Vella V, Pandini G, Vigneri P, Nicolosi ML, Gianì F, Vigneri R and Frasca F: Reactivation of p53 mutants by prima- 1 [corrected] in thyroid cancer cells. Int J Cancer 130: 2259-2270, 2012.

57 Izetti P, Hautefeuille A, Abujamra AL, de Farias CB, Giacomazzi J, Alemar B, Lenz G, Roesler R, Schwartsmann G, Osvaldt AB, Hainaut $\mathrm{P}$ and Ashton-Prolla P: PRIMA-1, a mutant p53 reactivator, induces apoptosis and enhances 
chemotherapeutic cytotoxicity in pancreatic cancer cell lines Invest New Drugs 32: 783-794, 2014.

58 Mohell N, Alfredsson J, Fransson Å, Uustalu M, Byström S, Gullbo J, Hallberg A, Bykov VJN, Björklund U and Wiman KG: APR-246 overcomes resistance to cisplatin and doxorubicin in ovarian cancer cells. Cell Death Dis 6: e1794, 2015.

59 Zhang W, Yi B, Wang C, Chen D, Bae S, Wei S, Guo R-J, Lu C, Nguyen LLH, Yang W-H, Lillard JW, Zhang X, Wang L and Liu R: Silencing of CD24 Enhances the PRIMA-1-Induced Restoration of Mutant p53 in Prostate Cancer Cells. Clin Cancer Res Off J Am Assoc Cancer Res 22: 2545-2554, 2016.

60 Li X-L, Zhou J, Chan Z-L, Chooi J-Y, Chen Z-R and Chng WJ: PRIMA-1met (APR-246) inhibits growth of colorectal cancer cells with different p53 status through distinct mechanisms. Oncotarget 6: 36689-36699, 2015.

61 Deben C, Lardon F, Wouters A, Op de Beeck K, Van den Bossche J, Jacobs J, Van Der Steen N, Peeters M, Rolfo C, Deschoolmeester V and Pauwels P: APR-246 (PRIMA1(MET)) strongly synergizes with AZD2281 (olaparib) induced PARP inhibition to induce apoptosis in non-small cell lung cancer cell lines. Cancer Lett 375: 313-322, 2016.

62 Lehmann S, Bykov VJN, Ali D, Andrén O, Cherif H, Tidefelt U, Uggla B, Yachnin J, Juliusson G, Moshfegh A, Paul C, Wiman KG and Andersson P-O: Targeting p53 in vivo: a firstin-human study with p53-targeting compound APR-246 in refractory hematologic malignancies and prostate cancer. J Clin Oncol Off J Am Soc Clin Oncol 30: 3633-3639, 2012.

63 Krayem M, Journe F, Wiedig M, Morandini R, Najem A, Salès F, van Kempen LC, Sibille C, Awada A, Marine J-C and Ghanem G: p53 Reactivation by PRIMA-1(Met) (APR-246) sensitises (V600E/K)BRAF melanoma to vemurafenib. Eur J Cancer Oxf Engl 1990 55: 98-110, 2016.

64 Malumbres M and Barbacid M: Cell cycle, CDKs and cancer: a changing paradigm. Nat Rev Cancer 9: 153-166, 2009.

65 Shapiro GI: Cyclin-dependent kinase pathways as targets for cancer treatment. J Clin Oncol Off J Am Soc Clin Oncol 24: 1770-1783, 2006.

66 Walker GJ, Flores JF, Glendening JM, Lin AH, Markl ID and Fountain JW: Virtually $100 \%$ of melanoma cell lines harbor alterations at the DNA level within CDKN2A, CDKN2B, or one of their downstream targets. Genes Chromosomes Cancer 22: 157-163, 1998.

67 Curtin JA, Fridlyand J, Kageshita T, Patel HN, Busam KJ, Kutzner H, Cho K-H, Aiba S, Bröcker E-B, LeBoit PE, Pinkel $\mathrm{D}$ and Bastian BC: Distinct sets of genetic alterations in melanoma. N Engl J Med 353: 2135-2147, 2005.

68 Monahan KB, Rozenberg GI, Krishnamurthy J, Johnson SM, Liu W, Bradford MK, Horner J, Depinho RA and Sharpless NE: Somatic p16(INK4a) loss accelerates melanomagenesis. Oncogene 29: 5809-5817, 2010.

69 Kannan K, Sharpless NE, Xu J, O'Hagan RC, Bosenberg M and Chin L: Components of the Rb pathway are critical targets of UV mutagenesis in a murine melanoma model. Proc Natl Acad Sci USA 100: 1221-1225, 2003.

70 Smalley KSM, Lioni M, Dalla Palma M, Xiao M, Desai B, Egyhazi S, Hansson J, Wu H, King AJ, Van Belle P, Elder DE, Flaherty KT, Herlyn M and Nathanson KL: Increased cyclin D1 expression can mediate BRAF inhibitor resistance in BRAF V600E-mutated melanomas. Mol Cancer Ther 7: 2876-2883, 2008 .
71 Jalili A, Wagner C, Pashenkov M, Pathria G, Mertz KD, Widlund HR, Lupien M, Brunet J-P, Golub TR, Stingl G, Fisher DE, Ramaswamy S and Wagner SN: Dual Suppression of the Cyclin-Dependent Kinase Inhibitors CDKN2C and CDKN1A in Human Melanoma. JNCI J Natl Cancer Inst 104: 1673-1679, 2012.

72 Kwong LN, Costello JC, Liu H, Jiang S, Helms TL, Langsdorf AE, Jakubosky D, Genovese G, Muller FL, Jeong JH, Bender RP, Chu GC, Flaherty KT, Wargo JA, Collins JJ and Chin L: Oncogenic NRAS signaling differentially regulates survival and proliferation in melanoma. Nat Med 18: 1503-1510, 2012.

73 Sheppard KE and McArthur GA: The cell-cycle regulator CDK4: an emerging therapeutic target in melanoma. Clin Cancer Res Off J Am Assoc Cancer Res 19: 5320-5328, 2013.

74 Robert C, Long GV, Brady B, Dutriaux C, Maio M, Mortier L, Hassel JC, Rutkowski P, McNeil C, Kalinka-Warzocha E, Savage KJ, Hernberg MM, Lebbé C, Charles J, Mihalcioiu C, Chiarion-Sileni V, Mauch C, Cognetti F, Arance A, Schmidt H, Schadendorf D, Gogas H, Lundgren-Eriksson L, Horak C, Sharkey B, Waxman IM, Atkinson $\mathrm{V}$ and Ascierto PA: Nivolumab in previously untreated melanoma without BRAF mutation. N Engl J Med 372: 320-330, 2015.

75 Topalian SL, Sznol M, McDermott DF, Kluger HM, Carvajal RD, Sharfman WH, Brahmer JR, Lawrence DP, Atkins MB, Powderly JD, Leming PD, Lipson EJ, Puzanov I, Smith DC, Taube JM, Wigginton JM, Kollia GD, Gupta A, Pardoll DM, Sosman JA and Hodi FS: Survival, durable tumor remission, and long-term safety in patients with advanced melanoma receiving nivolumab. J Clin Oncol Off J Am Soc Clin Oncol 32: 1020-1030, 2014.

76 Hodi FS, O’Day SJ, McDermott DF, Weber RW, Sosman JA, Haanen JB, Gonzalez R, Robert C, Schadendorf D, Hassel JC, Akerley W, van den Eertwegh AJM, Lutzky J, Lorigan P, Vaubel JM, Linette GP, Hogg D, Ottensmeier CH, Lebbé C, Peschel C, Quirt I, Clark JI, Wolchok JD, Weber JS, Tian J, Yellin MJ, Nichol GM, Hoos A and Urba WJ: Improved survival with ipilimumab in patients with metastatic melanoma. N Engl J Med 363: 711-723, 2010.

77 Daud A: Current and Emerging Perspectives on Immunotherapy for Melanoma. Semin Oncol 42(Suppl 3): S3-S11, 2015.

78 Niezgoda A, Niezgoda P and Czajkowski R: Novel Approaches to Treatment of Advanced Melanoma: A Review on Targeted Therapy and Immunotherapy. BioMed Res Int 2015: e851387, 2015.

79 Sumimoto H, Imabayashi F, Iwata $\mathrm{T}$ and Kawakami $\mathrm{Y}$ : The BRAF-MAPK signaling pathway is essential for cancerimmune evasion in human melanoma cells. J Exp Med 203: 1651-1656, 2006.

80 Khalili JS, Liu S, Rodríguez-Cruz TG, Whittington M, Wardell S, Liu C, Zhang M, Cooper ZA, Frederick DT, Li Y, Zhang M, Joseph RW, Bernatchez C, Ekmekcioglu S, Grimm E, Radvanyi LG, Davis RE, Davies MA, Wargo JA, Hwu P and Lizée G: Oncogenic BRAF(V600E) promotes stromal cell-mediated immunosuppression via induction of interleukin-1 in melanoma. Clin Cancer Res Off J Am Assoc Cancer Res 18: 5329-5340, 2012.

81 Wilmott JS, Long GV, Howle JR, Haydu LE, Sharma RN, Thompson JF, Kefford RF, Hersey P and Scolyer RA: Selective BRAF inhibitors induce marked T-cell infiltration into human metastatic melanoma. Clin Cancer Res Off J Am Assoc Cancer Res 18: 1386-1394, 2012. 
82 Liu C, Peng W, Xu C, Lou Y, Zhang M, Wargo JA, Chen JQ, Li HS, Watowich SS, Yang Y, Tompers Frederick D, Cooper ZA, Mbofung RM, Whittington M, Flaherty KT, Woodman SE, Davies MA, Radvanyi LG, Overwijk WW, Lizée G and Hwu P: BRAF inhibition increases tumor infiltration by $\mathrm{T}$ cells and enhances the antitumor activity of adoptive immunotherapy in mice. Clin Cancer Res Off J Am Assoc Cancer Res 19: 393-403, 2013.

83 Boni A, Cogdill AP, Dang P, Udayakumar D, Njauw C-NJ, Sloss CM, Ferrone CR, Flaherty KT, Lawrence DP, Fisher DE, Tsao $\mathrm{H}$ and Wargo JA: Selective BRAFV600E inhibition enhances T-cell recognition of melanoma without affecting lymphocyte function. Cancer Res 70: 5213-5219, 2010.

84 Jiang X, Zhou J, Giobbie-Hurder A, Wargo J and Hodi FS: The activation of MAPK in melanoma cells resistant to BRAF inhibition promotes PD-L1 expression that is reversible by MEK and PI3K inhibition. Clin Cancer Res Off J Am Assoc Cancer Res 19: 598-609, 2013.

85 Munshi A and Ramesh R: Mitogen-Activated Protein Kinases and Their Role in Radiation Response. Genes Cancer 4: 401408, 2013.

86 Bonner JA, Vroman BT, Christianson TJ and Karnitz LM: Ionizing radiation-induced MEK and Erk activation does not enhance survival of irradiated human squamous carcinoma cells. Int J Radiat Oncol Biol Phys 42: 921-925, 1998.

87 Bernhard EJ, Stanbridge EJ, Gupta S, Gupta AK, Soto D, Bakanauskas VJ, Cerniglia GJ, Muschel RJ and McKenna WG: Direct evidence for the contribution of activated $\mathrm{N}$-ras and $\mathrm{K}$ ras oncogenes to increased intrinsic radiation resistance in human tumor cell lines. Cancer Res 60: 6597-6600, 2000.

88 Sklar MD: The ras oncogenes increase the intrinsic resistance of NIH 3 T3 cells to ionizing radiation. Science 239: 645-647, 1988.

89 Chowdhary M, Patel KR, Danish HH, Lawson DH and Khan MK: BRAF inhibitors and radiotherapy for melanoma brain metastases: potential advantages and disadvantages of combination therapy. OncoTargets Ther 9: 7149-7159, 2016

90 Narayana A, Mathew M, Tam M, Kannan R, Madden KM, Golfinos JG, Parker EC, Ott PA and Pavlick AC: Vemurafenib and radiation therapy in melanoma brain metastases. J Neurooncol 113: 411-416, 2013.

91 Schick U, Kyula J, Barker H, Patel R, Zaidi S, Gregory C, Hafsi H, Roulstone V, Deutsch E, McLaughlin M and Harrington K: Trametinib radiosensitises RAS- and BRAF-mutated melanoma by perturbing cell cycle and inducing senescence. Radiother Oncol J Eur Soc Ther Radiol Oncol 117: 364-375, 2015.

92 Eder S, Lamkowski A, Priller M, Port M and Steinestel K: Radiosensitization and downregulation of heterogeneous nuclear ribonucleoprotein $\mathrm{K}$ (hnRNP $\mathrm{K}$ ) upon inhibition of mitogen/extracellular signal-regulated kinase (MEK) in malignant melanoma cells. Oncotarget 6: 17178-17191, 2015.

93 Joensuu H, Eriksson M, Collan J, Balk MH, Leyvraz S and Montemurro M: Radiotherapy for GIST progressing during or after tyrosine kinase inhibitor therapy: A prospective study. Radiother Oncol J Eur Soc Ther Radiol Oncol 116: 233-238, 2015

94 Arya AK, El-Fert A, Devling T, Eccles RM, Aslam MA, Rubbi CP, Vlatković N, Fenwick J, Lloyd BH, Sibson DR, Jones TM and Boyd MT: Nutlin-3, the small-molecule inhibitor of MDM2, promotes senescence and radiosensitises laryngeal carcinoma cells harbouring wild-type p53. Br J Cancer 103: $186-195,2010$
95 Supiot S, Hill RP and Bristow RG: Nutlin-3 radiosensitizes hypoxic prostate cancer cells independent of p53. Mol Cancer Ther 7: 993-999, 2008.

96 Fei P and El-Deiry WS: P53 and radiation responses. Oncogene 22: 5774-5783, 2003

97 McCubrey JA, Lertpiriyapong K, Fitzgerald TL, Martelli AM, Cocco L, Rakus D, Gizak A, Libra M, Cervello M, Montalto G, Yang LV, Abrams SL and Steelman LS: Roles of TP53 in determining therapeutic sensitivity, growth, cellular senescence, invasion and metastasis. Adv Biol Regul 63: 32-48, 2017.

98 Higuchi Y, Asaumi J, Murakami J, Matsuzaki H, Wakasa T, Inoue T, Shigehara H, Konouchi H, Hisatomi M, Kawasaki S, Hiraki Y and Kishi K: Effects of p53 gene therapy in radiotherapy or thermotherapy of human head and neck squamous cell carcinoma cell lines. Oncol Rep 10: 671-677, 2003.

99 Huh JJ, Wolf JK, Fightmaster DL, Lotan R and Follen M: Transduction of adenovirus-mediated wild-type p53 after radiotherapy in human cervical cancer cells. Gynecol Oncol 89: 243-250, 2003.

100 Kawabe S, Munshi A, Zumstein LA, Wilson DR, Roth JA and Meyn RE: Adenovirus-mediated wild-type p53 gene expression radiosensitizes non-small cell lung cancer cells but not normal lung fibroblasts. Int J Radiat Biol 77: 185-194, 2001.

101 Kim IA, Yang YJ, Yoon SC, Choi IB, Kay CS, Kwon HC, Kim CM, Joe YA, Kang JK and Hong YK: Potential of adenoviral p53 gene therapy and irradiation for the treatment of malignant gliomas. Int J Oncol 19: 1041-1047, 2001.

102 Pirollo KF, Hao Z, Rait A, Jang YJ, Fee WE, Ryan P, Chiang $\mathrm{Y}$ and Chang EH: p53 mediated sensitization of squamous cell carcinoma of the head and neck to radiotherapy. Oncogene 14 : 1735-1746, 1997.

103 Spitz FR, Nguyen D, Skibber JM, Meyn RE, Cristiano RJ and Roth JA: Adenoviral-mediated wild-type p53 gene expression sensitizes colorectal cancer cells to ionizing radiation. Clin Cancer Res Off J Am Assoc Cancer Res 2: 1665-1671, 1996.

104 Duan X, Zhang H, Liu B, Li X-D, Gao Q-X and Wu Z-H: Apoptosis of murine melanoma cells induced by heavy-ion radiation combined with Tp53 gene transfer. Int J Radiat Biol 84: 211-217, 2008.

105 Cao C, Shinohara ET, Subhawong TK, Geng L, Kim KW, Albert JM, Hallahan DE and Lu B: Radiosensitization of lung cancer by nutlin, an inhibitor of murine double minute 2 . Mol Cancer Ther 5: 411-417, 2006.

106 Lehmann BD, McCubrey JA, Jefferson HS, Paine MS, Chappell WH and Terrian DM: A dominant role for p53dependent cellular senescence in radiosensitization of human prostate cancer cells. Cell Cycle Georget Tex 6: 595-605, 2007.

107 Feng FY, Zhang Y, Kothari V, Evans JR, Jackson WC, Chen W, Johnson SB, Luczak C, Wang S and Hamstra DA: MDM2 Inhibition Sensitizes Prostate Cancer Cells to Androgen Ablation and Radiotherapy in a p53-Dependent Manner. Neoplasia NY N 18: 213-222, 2016.

108 Williams DJR, Zhang Y, Zhou H, Gridley DS, Koch CJ, Russell J, Slater JS and Little JB: A quantitative overview of radiosensitivity of human tumor cells across histological type and TP53 status. Int J Radiat Biol 84: 253-264, 2008.

109 Weichselbaum RR, Liang H, Deng L and Fu Y-X: Radiotherapy and immunotherapy: a beneficial liaison? Nat Rev Clin Oncol, 2017. 
110 Golden EB, Chhabra A, Chachoua A, Adams S, Donach M, Fenton-Kerimian M, Friedman K, Ponzo F, Babb JS, Goldberg J, Demaria S and Formenti SC: Local radiotherapy and granulocyte-macrophage colony-stimulating factor to generate abscopal responses in patients with metastatic solid tumours: a proof-of-principle trial. Lancet Oncol 16: 795-803, 2015.

111 Park SS, Dong H, Liu X, Harrington SM, Krco CJ, Grams MP, Mansfield AS, Furutani KM, Olivier KR and Kwon ED: PD-1 Restrains Radiotherapy-Induced Abscopal Effect. Cancer Immunol Res 3: 610-619, 2015.

112 Sharabi AB, Tran PT, Lim M, Drake CG and Deweese TL: Stereotactic radiation therapy combined with immunotherapy: augmenting the role of radiation in local and systemic treatment. Oncol Williston Park N 29: 331-340, 2015.

113 Vanpouille-Box C, Diamond JM, Pilones KA, Zavadil J, Babb JS, Formenti SC, Barcellos-Hoff MH and Demaria S: TGF $\beta$ Is a Master Regulator of Radiation Therapy-Induced Antitumor Immunity. Cancer Res 75: 2232-2242, 2015.

114 Ahn G-O, Tseng D, Liao C-H, Dorie MJ, Czechowicz A and Brown JM: Inhibition of Mac-1 (CD11b/CD18) enhances tumor response to radiation by reducing myeloid cell recruitment. Proc Natl Acad Sci USA 107: 8363-8368, 2010.

115 Chiang C-S, Fu SY, Wang S-C, Yu C-F, Chen F-H, Lin C-M and Hong $\mathrm{J}-\mathrm{H}$ : Irradiation promotes an $\mathrm{m} 2$ macrophage phenotype in tumor hypoxia. Front Oncol 2: 89, 2012.
116 Meng Y, Beckett MA, Liang H, Mauceri HJ, van Rooijen N, Cohen KS and Weichselbaum RR: Blockade of tumor necrosis factor alpha signaling in tumor-associated macrophages as a radiosensitizing strategy. Cancer Res 70: 1534-1543, 2010.

117 Demaria S, Pilones KA, Formenti SC and Dustin ML: Exploiting the stress response to radiation to sensitize poorly immunogenic tumors to anti-CTLA-4 treatment. Oncoimmunology 2: e23127, 2013.

118 Koller KM, Mackley HB, Liu J, Wagner H, Talamo G, Schell TD, Pameijer C, Neves RI, Anderson B, Kokolus KM, Mallon $\mathrm{CA}$ and Drabick JJ: Improved survival and complete response rates in patients with advanced melanoma treated with concurrent ipilimumab and radiotherapy versus ipilimumab alone. Cancer Biol Ther 18: 36-42, 2017.

119 Sharabi A, Nirschl C, Ceccato T, Nirschl T, Francica B, Alme A, Velarde E, DeWeese $\mathrm{T}$ and Drake C: Role of Radiation Therapy in Inducing Antigen Specific Antitumor Immune Responses When Combined With Anti-PD1 Checkpoint Blockade: Mechanism and Clinical Implications. Int J Radiat Oncol Biol Phys 90: S1, 2014.

Received April 28, 2017

Revised May 18, 2017

Accepted May 19, 2017 